\title{
Editorial
}

\section{Enfermedades infecciosas emergentes y reemergentes}

\author{
Consuelo Giménez Pardo \\ Secretaria Académica de la Facultad de Medicina y Ciencias de la Salud (UAH) y subdirectora adjunta de \\ RIECS; consuelo.gimenez@uah.es; ORCID id: https://orcid.org/0000-0002-8206-1952
}

DOI: https://doi.org/10.37536/RIECS.2021.6.1.260

Las enfermedades emergentes definidas como nuevas infecciones que resultan de la evolución o modificación de un agente patógeno que cambia, bien de hospedador, de vector o que cambia su patogenicidad, incluyen también a aquellas enfermedades desconocidas hasta el momento de su aparición. Las enfermedades reemergentes son infecciones ya conocidas que, o bien cambian su ubicación geográfica, su espectro de hospedadores se amplía o su prevalencia aumenta. La mayoría de las enfermedades emergentes aparecidas en los últimos tiempos son de origen animal y casi todas ellas son potencialmente zoonóticas.

En líneas generales en la transmisión de los patógenos emergentes se consideran, tres fuentes: la propia población hospedadora, como es el caso del hombre en la tuberculosis; el ambiente exterior, como ocurre con la legionelosis y, la presencia de hospedadores diferentes, lo que implica un salto en la barrera de especie, como sucede con la encefalopatía espongiforme bovina, la encefalitis por lisavirus, el SIDA o el reciente SARS-CoV-2, entre otros.

En un mundo globalizado, la aparición y transmisión de estas enfermedades tiene que ver con cuestiones multifactoriales que interaccionan entre sí y entre las que citamos algunas:

- La producción de alimentos y los cambios en los hábitos y costumbres en la alimentación.

- Las actividades al aire libre: viajes, recreación, y deportes.

- Cambios ambientales, cambios en el uso del agua, así como el calentamiento global.

- Prácticas de deforestación-reforestación que han causado modificación de los periodos de inundación-sequía, que, a la vez, generan hambrunas en muchas zonas del planeta, y por tanto mayor vulnerabilidad a toda clase de enfermedades.

- Programas de prevención en salud pública y en salud animal, así como infraestructuras para la vigilancia epidemiológica con pocos recursos: falta de personal entrenado (epidemiólogos, científicos y especialistas en el control de vectores y reservorios, entre otros).

- Restricciones económicas, u organizativas para el control de las enfermedades previamente controladas.

- $\quad$ El uso indiscriminado de antibióticos y drogas en el hombre y en los animales.

- Adaptación de los agentes patógenos en cuanto a virulencia.

- Salida de enfermedades hacia nuevos ecosistemas por la vía del transporte de personas y del comercio (mercancías y animales).

- Enfermedades conocidas que se desplazan a nuevas áreas geográficas y a nuevas poblaciones.

- Cambios en las decisiones gubernamentales respecto de las prioridades de atención a la salud.

- Los fenómenos sociales, los conflictos civiles, el deterioro urbano, y los desastres naturales que generan empobrecimiento económico.

- El crecimiento demográfico global y el aumento de la densidad de población en zonas concretas. 
El virus de la rabia, como la zoonosis más antigua descrita, los virus de Influenza H5N1 y H1N1 causantes de las conocidas fiebre aviar y porcinas, respectivamente, o la pandemia que estamos viviendo por el coronavirus SARS-CoV-2, son ejemplos de zoonosis emergentes. No perdemos de vista a los virus de Hendra y Nipah, paramyxovius causantes de enfermedades con sintomatología respiratoria y neurológica en el caballo y el cerdo, respectivamente, que ya han ocasionado casos mortales en humanos; o los arenavirus del Nuevo Mundo (Junin, Machupo y Guanarito) causantes de las fiebres hemorrágicas argentina, boliviana y venezolana, respectivamente, transmitidos por roedores silvestres. Como bacterias emergentes destacaremos, la cepa O157:H7 de Escherichia coli transmitida a través de alimentos contaminados, con brotes de diarreas sangrantes y a veces síndrome urémico hemolítico en Norteamérica, Europa y Japón. En reemergencias víricas destacamos la del dengue con fiebre hemorrágica en Asia, que también se ha presentado en América Central y del Sur en diferentes epidemias. No nos olvidamos de la fiebre amarilla. Como reemergencias bacterianas citaremos el cólera y la meningitis cerebroespinal. Así las cosas, el panorama global no se vislumbra alentador. La capacidad de mutación de los virus y su tendencia a modificar su afinidad hacia diferentes especies de hospedadores, dejan en clara su adaptabilidad para infectar a los seres humanos, y junto a las actividades propias de una población en constante crecimiento, son buenos ingredientes para otras futuras pandemias.

Relacionado con esto parecen claras dos cuestiones, una es que las enfermedades zoonóticas constituyen una amenaza continua para toda la población humana, independientemente de la edad, el género, la forma de vida, los antecedentes étnicos, y el nivel socioeconómico. La otra es que existe una conexión entre la salud animal, humana y ambiental y por ello necesitamos del estudio de estas enfermedades en su ámbito biológico, ecológico, médico y económico con el fin de garantizar la salud global de las poblaciones. Además, es necesario que las tres organizaciones internacionales implicadas en estos problemas, la OIE (Organización Mundial de Sanidad Animal), la FAO, (Organización de las Naciones Unidas para la Agricultura y la Alimentación) y la OMS (Organización Mundial de la Salud) cooperen y trabajen conjuntamente. La OMS ya ha avisado que la COVID-19 no será la última zoonosis emergente causante de una emergencia sanitaria ni la última pandemia que padecerá el mundo, basta saber si estamos preparados para hacer frente a la próxima. 